\title{
Giant Canine Ovarian Teratoma: Case Report
}

Dionney Albuquerque da Costa ${ }^{1}$, Maria Rogéria Menezes da Silva ${ }^{2}$, Natália Freitas de Souza', Washington Luiz Assunção Pereira ${ }^{1}$ and Adriana Maciel de Castro Cardoso ${ }^{1 *}$

1 Institute of Animal Health and Production (ISPA), Veterinary Pathology Sector (LABOPAT), Federal Rural University of Amazonia (UFRA), Belém, PA, Brazil

${ }^{2}$ Medica VeterináriaAutônoma, Ananindeua, $P A$, Brazil

\begin{abstract}
The incidence of cancers in domestic dogs has increased greatly in recent years, drawing interest from areas such as oncology, clinical and veterinary pathology. Among these tumors, it has been highlighted the ovarian neoplasms such as ovarian teratoma, rare in domestic animals and it is characterized by the composition of multiple tissues foreign to the ovary, such as skin and appendages, bone, fat, nerve, occurring more frequently in young animals. This study aimed to report a case of ovarian teratoma in a German Shepard dog, two years old, which received treatment in the Veterinary Hospital at the Federal Rural University of Amazonia. The animal was euthanized and the complete necropsy examination was performed. The thoracic cavity was inspected and it was evident the presence of serosanguineous fluid aspect. In the abdominal cavity, it was observed a large intra abdominal mass rounded in shape and irregular surface, lobulated, firm consistency with cystic aspect structuresOn histopathological examination of the abdominal mass, it was observed several types of tissues such as adipose tissue, cartilaginous plates and presence of cysts containing keratin material. The results corroborate those reported in the literature studied.
\end{abstract}

Keywords: Ovarian neoplasia; Tumor; Domestic animals; Teratoma

\section{Introduction}

Nowadays, incidence of neoplasms in domestic canids is increasing and it is a growing area in veterinary medicine [1]. Neoplasms are abnormal masses of cells, which developed in an uncoordinated way compared to adjacent normal tissue. Ovarian neoplasias can be classified according to the embryological derivation of the predominant cellular constituent: epithelial cells tumour (adenoma and adenocarcinoma); germ cells tumour (teraroma and dysgerminoma) and sex cord stromal tumour (granulosa cells tumour, interstitial cells tumour, luteoma and thecoma) [2].

The canine ovarian teratoma is a rare neoplasia in domestic animals; however, it has been mostly described in a bitch. Teratomas are composed of abnormal tissue derived from two or all three germinal layers. It can have solid or cystic areas in the surface besides other tissues such as bone, cartilage and teeth. Most of these tumours are benign, nonetheless, some of the tissues can make it a malignant [3-5].

This work aimed to report the occurrence of a giant canine ovarian teratoma, diagnosed at the Veterinary Pathology Laboratory, Federal Rural University of Amazonia, accentuating the macroscopic and the histopathological behaviour, as a contibution to the veterinary Oncology, since it is a rare and invasive tumor.

\section{Case Report}

A dog, German Shepard, whole, nulliparous, two years, nine months and two days' old received treatment in the Veterinary Hospital at the Federal Rural University of Amazonia, presenting edema in hind limbs and ascites besides dyspnea. The animal received care before arriving at the hospital, being submitted to abdominocentesis, with removal of a large amount of abdominal fluid. Testes were made for renal and liver functions and abdominal ultrasonography, where it was found the patient had an abdominal mass occupying approximately $90 \%$ of the respective cavity.

The animal was never pregnant and never uses contraceptives. In the clinical examination, was notice poor general health condition, diminish skin turgor, pale ocular and oral mucosae, popliteal lymph node infarcted, pain sensibility to abdominal palpation and distended abdomen. The animal presented dyspneic, with rattle on auscultation. In this case, the procedure adopted was partial drainage of the abdominal fluid where it was observed large amount of haemorrhagic fluid. The complete blood count was performed.

In the radiographic exam it was confirmed the presence of intrathoracic fluid, hidering the auscultation of the organs in the area, thoracic effusion, intra-abdominal fluid and volume increase in the area dislocating the organs, such as intestinal loops.

Due to the serious health condition in which the animal was presented, it was decided to do euthanasia. The body was referred to the Veterinary Pathology sector for the necropsy. It was conducted external and internal evaluation through the anatomopathologic evaluation of the viscera, filling of the necropsy form with full description of the alterations, photographic documentation and collection of material for histopathological exam.

Except for the neoplastic tissue, after 24 hours, the samples already fixed in buffered formaldehyde were cut and placed in cassettes, being sending to processing by routine paraffin embedding technique: dehydration in four baths of different ethyl alcohol concentration $(70 \%$ to $100 \%)$, clarification in two baths of xylol and inclusion in paraffin, obtaining blocks. They were cut by a microtome to $5 \mu \mathrm{m}$ and collected onto glass slides. For the neoplastic tissue, the procedure undertaken

*Corresponding author: Cardoso AMC, Animal Health and Production Institute Department of Pathology, Federal Rural University of Amazonia, Av. Presidente Tancredo Neves, no2501, 66077-901, Belém, PA, Brazil, Tel: +55 91988195336 E-mail: drikamaciel@yahoo.com.br

Received June 07, 2017; Accepted July 08, 2017; Published July 15, 2017

Citation: da Costa DA, da Silva MRM, de Souza NF, Pereira WLA, Cardoso AMDC (2017) Giant Canine Ovarian Teratoma: Case Report. J Cytol Histol 8: 463. doi: $10.4172 / 2157-7099.1000463$

Copyright: @ 2017 da Costa DA, et al. This is an open-access article distributed under the terms of the Creative Commons Attribution License, which permits unrestricted use, distribution, and reproduction in any medium, provided the original author and source are credited. 
Citation: da Costa DA, da Silva MRM, de Souza NF, Pereira WLA, Cardoso AMDC (2017) Giant Canine Ovarian Teratoma: Case Report. J Cytol Histol 8: 463. doi: 10.4172/2157-7099.1000463

was decalcification in the decalcification solution for three days and it has been processed routinely [6].

The slides were treated with xylol and rehydrated, stained with haematoxylin-eosin (H\&E) and assembled for histological evaluation in microscope.

\section{Results and Discussion}

On the external examination, the animal had a poor general condition, hair bristling, soft faeces which were brownish in colour in the perianal region, leakage of serosanguineous exudate, from the bilateral nasal cavity and distension of the abnormal cavity (Figure 1).

The thoracic cavity was inspected and it was evident the presence of serosanguineous fluid aspect (approximately, $700 \mathrm{~mL}$ ). In the abdominal cavity, it was observed a large intra-abdominal mass rounded in shape and irregular surface, lobulated, firm consistency with cystic aspect structures, besides a significant amount of serosanguineous fluid (approximately, $2500 \mathrm{~mL}$ ). The mass measured $55.0 \mathrm{~cm}$ in circumference in its longest axis. The mass was connected to the right uterine horn and the contralateral ovary showed no visible alterations (Figure 2). At the transversal section, the mass showed areas from cartilaginous to calcified, as well as hair and large amount of adipose tissue (Figure 3).

On the histopathological examination, it was observed several types of tissue such as adipose tissue, cartilaginous plates, and presence of structures with cystic aspect containing keratin and squamous epithelium ranging to the simple cubic. In addition, areas

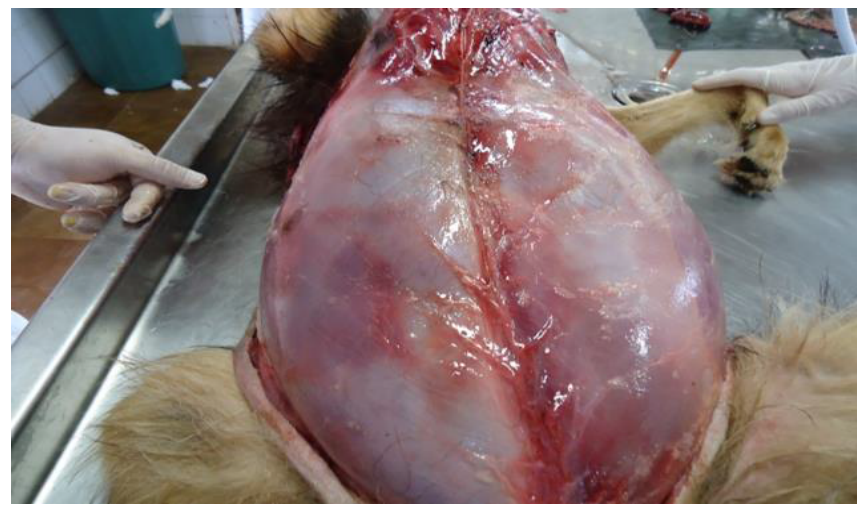

Figure 1: Dorsal view of the abdominal distension.

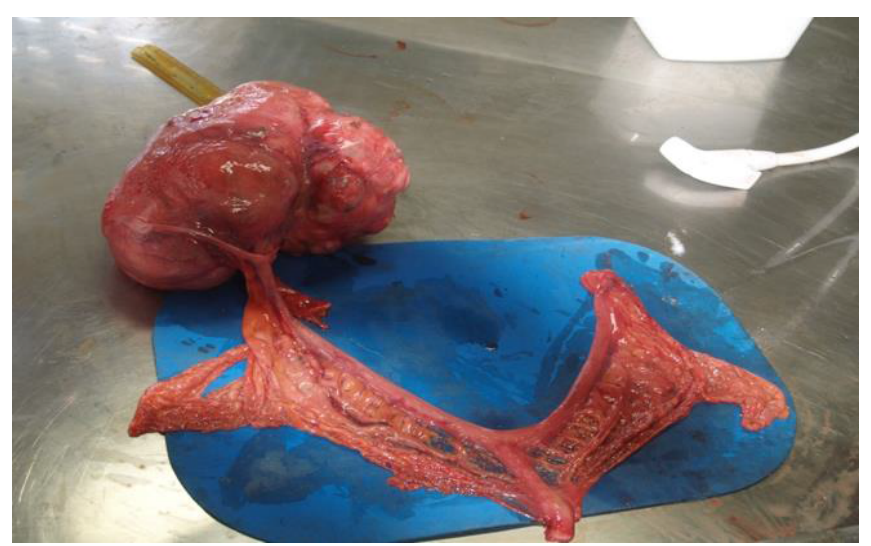

Figure 2: Mass connected to the uterine horn. Contralateral ovary preserved.

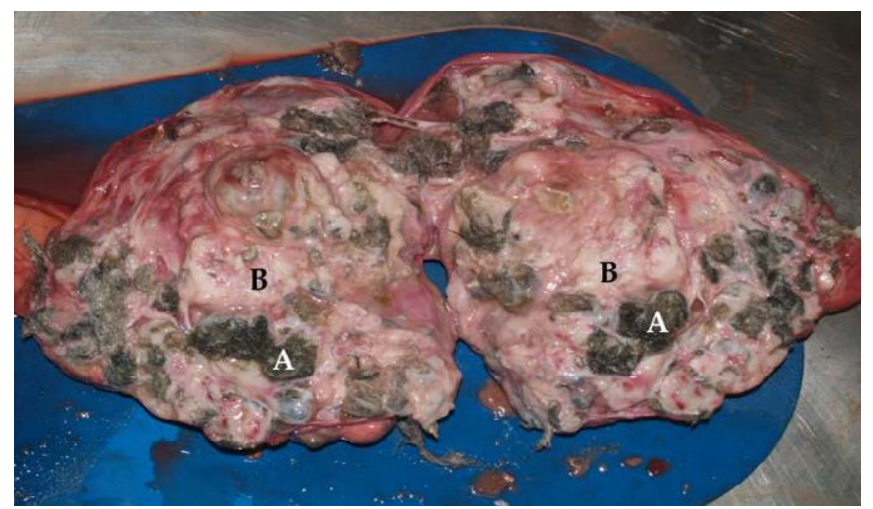

Figure 3: Crosscutting surface of the intra-abdominal mass containing bones, cartilaginous tissue and hair (A), and large amount of adipose tissue (B).

with epidermal and dermal tissue containing stratified squamous epithelium and areas of hyperkeratinisation besides corneas lamellae, several follicles, few hair and sebaceous glands (Figure 4A and 4B).

Regarding age, according to the literature, these tumours occur more frequently in young animals [4,5,7-11]. Similar situation was found in the present study, since it is a female dog two years and nine months old.

The animals affected by ovarian teratoma, frequently presents a large abdominal mass where it could be asymptomatic or presenting clinical signs such as depression, weight loss, anorexia, oedema in hind limbs and lymphadenopathy $[7,11-13]$.

Physical examination may also show clinical sigh as apathy, cachexia, pale mucosae, hypothermia, tachycardia, tachypnea and abnormal lung sounds. Partially, the animal in a matter had showed similar clinical signs as a result of the alterations caused by the dimension and localization of the neoplasia.

The results of the $\mathrm{CBC}$ are below (Table 1). In the result, was observed microcytic anaemia due to the low number of red blood cells, haematocrit and haemoglobin. It indicates that the organism is responding to an infectious process, with a high number of neutrophils and rod cells $[14,15]$. Other authors also observed in the complete blood count from distinct cases involving ovarian teratoma in a female dog, leucocytosis, neutrophilia and lymphopenia $[16,17]$.

In neoplastic diseases, there is a huge frequency of abnormalities in peripheral hematopoietic cells. Reductions in the number of erythrocytes and platelets are also observed as a result of a deficient erythropoiesis or increased the destruction of hematopoietic cells [18].

Concerning localization, the literature reports that the left ovary appears to be involved more often than the right $[5,10,19]$. The contralateral ovary is commonly normal in animal which are affect with the unilateral form, it contributes to the maintenance of oestrous cycle $[3,13]$. However, the opposite was observed in the reported case (Figure 2).

Some writers assert that through the histopathological examination of abdominal mass fragments confirming the diagnostic of ovarian teratoma in dog, the presence of elements, for instance, epithelial tissue, cartilaginous plates, well differentiated adipose tissue and bone tissue (osteoid) $[2,5,11]$.

In addition, Assis et al. [16] also describe the alterations found in 
Citation: da Costa DA, da Silva MRM, de Souza NF, Pereira WLA, Cardoso AMDC (2017) Giant Canine Ovarian Teratoma: Case Report. J Cytol Histol 8: 463. doi: 10.4172/2157-7099.1000463

Page 3 of 3

\begin{tabular}{|c|c|c|c|c|}
\hline \multicolumn{5}{|c|}{ Complete Blood Count } \\
\hline Red blood cells $(5,5-8,5)$ & 4,600 (millions $/ \mathrm{mm}^{3}$ ) & Total leukocyte $(6,000-17,000)$ & 28,800 & $\mathrm{~mm}^{3}$ \\
\hline Haemoglobin (12-18) & $11,800 \mathrm{~g} \%$ & Metamyelocyte & $0,000 \%$ & 0 \\
\hline Haematocrit (37-55) & $32,500 \%$ & Rod cells $(0-3000)$ & $6,000 \%$ & 2. \\
\hline MCV (60-77) & 70,652 u3 & Segmented $(3,000-11,500)$ & $88,000 \%$ & 25,344 \\
\hline MHC (19-23) & $25,652 \mathrm{pg}$ & Eosinophils & $0,000 \%$ & 0 \\
\hline MCHC (32-36) & $36,307 \%$ & Basophils (rare) & $0,000 \%$ & 0 \\
\hline Total Proteins & $0,000 \mathrm{~g} \%$ & Lymphocyte $(1,000-4,800)$ & $3,000 \%$ & 864 \\
\hline Platelets (200-500) & $450,000 \mathrm{mil} / \mathrm{mm}^{\prime}$ & Monocytes $(150-1,350)$ & $3,000 \%$ & 864 \\
\hline
\end{tabular}

Note: light hypochromia.

Table 1: Results of the complete blood count, evidencing the alterations.

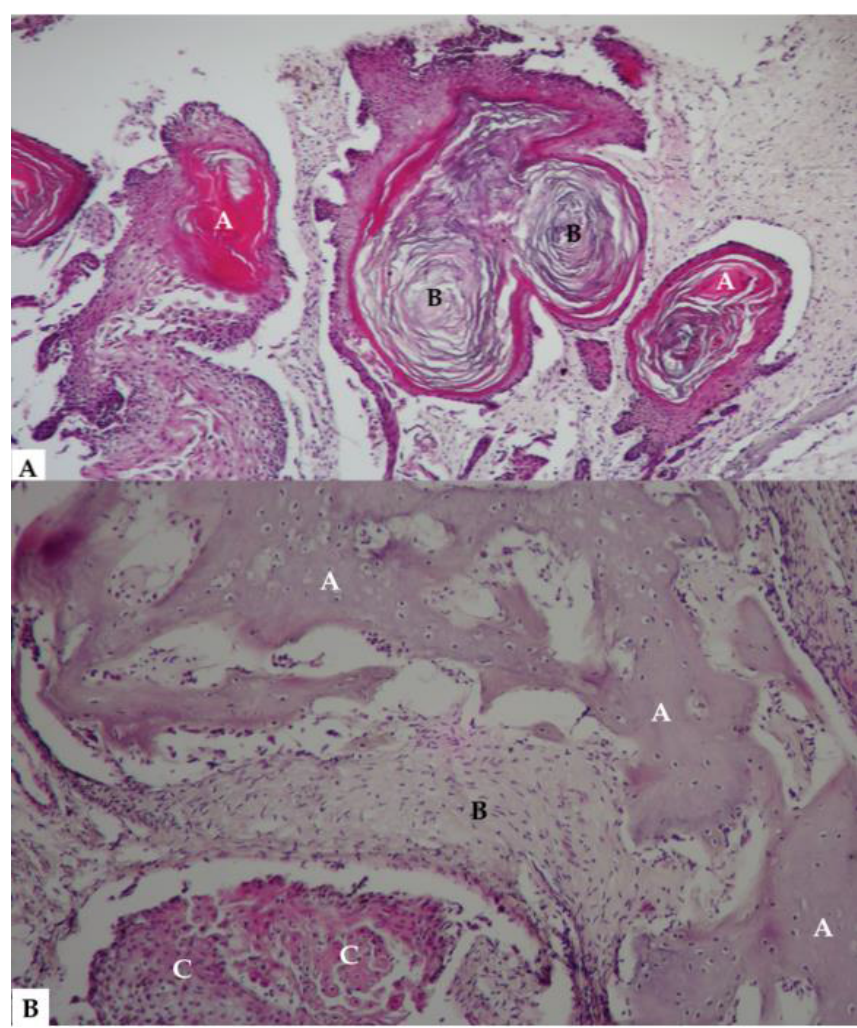

Figure 4: A. structures containing keratin material $(A)$ and lamellae $(B)$, showing some variation from squamous epithelium to simple cubic; B. osteoid tissue (A), showing normal pattern, near to the connective tissue with dermic tissue characteristics (B), and epidermis (C). H.E. 10X.

his study through microscopic fragments obtained from the abdominal mass. It was compatible with benign neoplasia, originated from primordial germ cells composed of mesenchymal cells, represented by connective tissue and in the epithelial portion composed by stratified squamous keratinized tissue and areas of necrosis [16].

\section{Conclusion}

In the present report, the clinical and microscopic findings in association with microscopic tissue characteristics substantiate the diagnosis of unilateral benign cystic ovarian teratoma, which is a rare neoplasm that present itself as a huge mass and occur more often in young animals, and it is similar to what has been previously reported.

\section{References}

1. Withrow SJ (2007) Why Worry About Cancer in Pets? In: Vail (eds.) Withrow and Macewen's small animal clinical oncology (4thedn), 15 a 17, Missouri: Saunders Elsevier.
2. Meuten DJ (2016) Tumor in domestic animals (5thedn), North Carolina: WileyBlackwell 1-14.

3. Dillberger JE, Altman NH (1987) A canine ovarian germ cell tumor with extraembryonic differentiation Veterinary Pathology 24: 96-98.

4. Jones TC, Hunt RD, King NW (2000) Patologia Veterinária 6ed São Paulo: Manole 14-15.

5. Vanhaesebrouck E, Govaere J, Smits K, Vercauteren G, Martens A, et al. (2010) Ovarian teratoma in the mare: a review and two cases Vlaams Diergeneeskundig Tijdschrift 79.

6. Caputo LFG, Gitirana LB, Manso PPA (2010) Técnicas hitológicas In: Conceitos e métodos para a formação de profissionais em laboratórios de saúde (Volume 2) Rio de Janeiro: EPSJV IOC 2: 254

7. Gorman ME, Bildfell R, Séguin B (2010) What is your diagnosis? Peritoneal fluid from a 1-year-old female German Shepherd dog. Veterinary clinical pathology 39: 393-394.

8. Blaszak B, Walkowski M, Ibbs M Jaskowski JM (2009) Teratoma adultum in a bitch: a case report. Veterinarni Medicina 54: 379-381.

9. Nielsen SW, Moulton JE (1990) Tumors of genital system In Mouton J E Tumors in domestic animals 3 Ed Berkeley: University of California Press 458-491.

10. Tappin S Norman D (2007) What is your diagnosis? Ovarian teratoma The Journal of Small Animal Practice 48: 53-55.

11. Thome HE, Moura VMBD, Flor DA (2006) Teratoma maligno em cadela: relato de caso Clínica Veterinária, São Paulo 11: 62-66.

12. North SM, Banks TA (2009) Small animal oncology: an introduction Saunders/ Elsevier 304.

13. Johnston SD, Kustritz MVR, Olson PNS (2001) Disorders of the canine ovary. In: Canine and feline theriogenology Philadelphia: WB Saunders, pp: 193-205.

14. Bush BM (2004) Interpretação de Resultados Laboratoriais para Clínicos de Pequenos Animais 1 ed São Paulo: Rocap 100-148.

15. Latimer KS, Meyer DJ (1997) Os leucócitos na Saúde e na Moléstia In: Ettinger S J Tratado de medicina Interna Veterinária 3 ed São Paulo: Manole 4: 26162664

16. Assis AR, Paiva FD, Facco GG, Estrada RA, Martín CM (2012) Aspectos ultrassonográficos de teratoma ovariano cístico benigno unilateral associado à peritonite em cadela rottweiller-relato de caso Congresso Paulista de Especialidades Disponível em.

17. Drumond KO, Quessada AM, Silva LS, Cruz NEA, Costa FAL, et al. (2008) Teratoma ovariano maligno em cadela gestante. Ciência Veterinária nos Trópicos 11: 81-85.

18. Zuckerman KS (1998) Hematopoietic abnormalities in patients with cancer. Cancer Control 5: 6-11

19. Rota A, Tursi M, Zabarino S Appino S (2013) Monophasic Teratoma of the Ovarian Remnant in a Bitch Reprod Dom Anim 48: 26-28. 